\title{
Bureaucracy Challenges and Prospects of Transfer of Authority to Provide Secondary Education in North Sumatra Province
}

\author{
Februati Trimurni ${ }^{1,{ }^{*}}$ Rudi Kristian P.M. ${ }^{2}$, Wiro Oktavius Ginting ${ }^{3}$ \\ ${ }^{1}$ Department of Public Administrastion, Universitas Sumatera Utara \\ ${ }^{2}$ Department of Public Administrastion, Universitas Sumatera Utara \\ ${ }^{3}$ Department of Public Administrastion, Universitas Sumatera Utara \\ Email:februati@usu.ac.id
}

\begin{abstract}
This study examines the challenges of public bureaucracy and the prospect of transferring authority to administering secondary education after the regulation of Law No. 32/2014 concerning Regional Government. Secondary education as a government affair that is concurrent affair in nature is transferred from the district/municipal government to the authority of the provincial government. Base on the policy, this study further formulates the problem of whether the transfer of authority has an impact on the regional bureaucracy and whether the transfer of authority makes the management of senior secondary education more efficient, effective and transparent. The research is conducted in two district/municipal autonomous regions in North Sumatra Province, namely Batubata Regency as a representation of rural areas and Medan City as a representation of urban areas and. The study is a qualitative research using in-depth interviews and secondary data as the main data collection tool. Informants from the study consisted of government officials, educators, and parents of students, local citizen and non-governmental organizations. The study finds that the transfer of authority poses a serious challenge to regional bureaucracies, especially in the transfer of basic institutional tasks, transfer of resources and transfer of assets, besides having a negative impact on aspects of supervision and control. However, this transfer provides the potential for the realization of the embryo of bureaucratic neutrality, transparency, reducing nepotism practice and increasing the competence of educators. This study further recommends the need for special instruments in strengthening the transition process both at the regulatory and advanced planning levels so that the ideal goal of creating quality, equitable and equitable secondary education can be realized.
\end{abstract}

Keywords: bureaucracy, authority and local government

\section{INTRODUCTION}

The administration of governance in the education sector after the 1998 political reform is focused on the devolutive authority of the district/municipality. This is in line with the focus or pendulum of regional autonomy, which is implemented at the district/municipality level. The principle of granting devolutive authority on a regular basis is regulated in the Law on Regional Government through Law No. 22/1999 and Law No. 32/2004. However, over time, the central government through Law No. 23/2014 revised the mechanism for local government administration. One of the important substances in the new regulation is the transfer of the authority to manage secondary education which was previously the authority of the district/municipal autonomous region to become the authority of the provincial government.
The regulation on regional government also reaffirms that the governance of the education sector is a concurrent affair or authority that is shared between the central government, provincial governments and district/municipal governments. The central government has the authority to manage higher education while the provincial government has the authority to manage secondary education and special education. District/municipal governments that previously had the authority to manage secondary education were only given the authority to manage basic education and early childhood education as well as non-formal education.

When viewed from other aspects related to education management at all levels, the government remains the dominant party in terms of curriculum determination, accreditation of educational institutions and determining the formation of educators and 
teaching staff in educational units. With the new regulation, autonomous regions at the provincial and district/municipal levels only have a little authority in the education sector, for example, only limited to determining local content curriculum at the level of education under their authority or transferring educators and education staff within the geographical scope of their jurisdiction.

Table 1. Division of Authority between Provincial and District/Municipal Governments

\begin{tabular}{|c|c|c|c|}
\hline $\begin{array}{l}\mathrm{N} \\
\mathrm{o}\end{array}$ & Sub Sector & Province & $\begin{array}{l}\text { District/Municip } \\
\text { al Governments }\end{array}$ \\
\hline 1. & $\begin{array}{l}\text { Education } \\
\text { Manageme } \\
\text { nt }\end{array}$ & $\begin{array}{l}\text { - Manageme } \\
\text { nt of } \\
\text { secondary } \\
\text { education } \\
\text { and special } \\
\text { education }\end{array}$ & $\begin{array}{l}\text { Management } \\
\text { of basic } \\
\text { education, } \\
\text { PAUD and } \\
\text { non-formal } \\
\text { education. }\end{array}$ \\
\hline 2. & Curriculum & $\begin{array}{l}\text { Determinin } \\
\mathrm{g} \quad \text { local } \\
\text { content } \\
\text { curriculum } \\
\text { for } \\
\text { secondary } \\
\text { education } \\
\text { and special } \\
\text { education. }\end{array}$ & $\begin{array}{l}\text { Determining } \\
\text { local content } \\
\text { curriculum } \\
\text { for basic } \\
\text { education, } \\
\text { PAUD and } \\
\text { non-formal } \\
\text { education }\end{array}$ \\
\hline 3. & $\begin{array}{l}\text { Accreditati } \\
\text { on }\end{array}$ & $\begin{array}{ll}\text { - No } \\
\text { authority }\end{array}$ & - No authority \\
\hline 4. & $\begin{array}{l}\text { Educators } \\
\text { and } \\
\text { Education } \\
\text { Personnel }\end{array}$ & $\begin{array}{l}\text { - } \begin{array}{l}\text { Transfer of } \\
\text { educators }\end{array} \\
\text { and } \\
\text { education } \\
\text { personnel } \\
\text { across } \\
\text { districts/cit } \\
\text { ies. }\end{array}$ & $\begin{array}{l}\text { - Transfer of } \\
\text { educators } \\
\text { and } \\
\text { education } \\
\text { personnel } \\
\text { within } \\
\text { districts/citie } \\
\text { s }\end{array}$ \\
\hline
\end{tabular}

Source: Adopted from Law No 23/2014.

The transformation of the authority for administering government and public services in the secondary education sector which was previously the domain of the district/municipal to become the domain of the provincial government cannot be separated from the pros and cons in the community. Those who support the policy are of the opinion that the decision is based on the need for efficiency and effectiveness in the delivery of services in the education sector, the need for equal distribution of education quality between regions within a province, the need for districts/cities to focus on basic education, efforts to avoid practical political activities in senior secondary education management and vocational education (Herawati, 2017; Central Kalimantan Disdik, 2017). Meanwhile, the contra view there is no guarantee that political activities are practical in intervening in education management, the distance of access and span of control between educational institutions and official institutions at the provincial level, education management arrangements that require a long time, loss of district/municipal potential cities that are apparently able to provide high school and vocational education well and the loss of regional resources such as various types of insurance and subsidies that have already been invested in the senior secondary and vocational education sector (Habibi, 2017).

Apart from the pros and cons of the transformation of authority, the Constitutional Court as the last bastion in guarding the substantial and technical truth of regulations at the law level against the constitution has made decisions on polemics and the pros and cons of the regulation of Law Number 23 of 2014. The Court in its decision stated that the regulations related to the transfer of authority for the administration of senior secondary and vocational education from the district/municipal to the provincial authority did not violate the constitution because in essence the administration of education became the authority between different levels of government can be divided or concurrent authority and is based on the principles of accountability, efficiency and externalities as well as national strategic interests which are the policies of the legislators that do not conflict with the Constitutionof 1945.

The process of transferring educational institutions, implementing personnel and education services as well as transferring assets has been carried out jointly by provincial and district/municipal governments throughout Indonesia for at least the last 6 six years. Several regions have completed the transformation of authority without significant obstacles, but several regions have not completed the transformation completely by early 2021. North Sumatra Province as one of the autonomous regions with a wide geographical area in Indonesia, accompanied by a large number of secondary education institutions, the uneven regional economic development as well as the distance of several districts/cities which are quite far from the province as the holder of the authority for managing secondary education make this transformation policy important to study.

This study will specifically examine the efficiency and effectiveness of public service delivery in the education sector and the prospects for the transfer of authority from the perspective of public administration. This article will further examine the impact of the transfer of authority for regional bureaucracies as well as improving the quality of public services. The impact of the transfer of authority for regional bureaucracies will be reviewed from aspects of the administrative system, institutional arrangement and hierarchy, human resource management and organizational span of control. While the impact on improving the quality of public services will be related to the transparency of public services, reliability and responsiveness. 


\section{LITERATURE REVIEW}

Discussion about the transfer of authority for the management of secondary education cannot be separated from the discussion about decentralization. Decentralization in the sense of devolution has given very broad authority to district/municipal governments in administering government and public services in the regions. This regulation also emphasizes that regional autonomy as a political consequence of the practice of decentralization provides a pendulum point for districts and cities. It can almost be said that the provincial government as an autonomous region also only has residual authority or administration of government and public services that cannot be carried out by regencies/municipalities or administration that crosses the geographical boundaries of several regencies/ municipalities. It is not wrong if the devolution carried out based on Law No. $22 / 1999$ is politically often referred to as the granting of the widest possible autonomy. The issuance of Law No. 23/2014 automatically reduces the authority of district/municipal governments so that the context of autonomy as broadly as possible is again a question.

Decentralization itself is a general concept which is undertaken from the practice of private organizations. Some of the reasons for decentralization by private organizations include closing the gap between the central organization and business production, sales and service units in addition to creating budget efficiency and budget oversight effectiveness (Common et al, 1998). The choice of decentralization is essentially inseparable from the fact that decentralization can lead the region to increase efficiency and effectiveness in the administration of power, implementation of government and public services (Rondinelli et al., 1984; Mawhood, 1983; Tiebout, 1956; Sujarwoto; 2017). At a further level, decentralization is considered capable of increasing accountability, democracy, participation, transparency and economy in autonomous regions (Burki et.al, 1999; Oates, 1972; Mills, 1990). The context of regional autonomy in Indonesia is ultimately the estuary of the decentralized system which is the reform agenda of the Indonesian nation (Armansyah, 2016). Decentralization in the sense of devolution has had a major impact on organizational, institutional and governance in the regions. Great authority as a result of devolution must be divided evenly through the establishment of government institutions at the local level accompanied by the affirmation of administrative systems, human resource management and regional institutional hierarchies. By Weber this context is referred to as bureaucracy (Denhardt, 2008).

Bureaucracy is generally known as a concept to interpret as a form of government where there are people who work for the government, an administrative efficiency system where there are layers of organization and a hierarchy of authority and pejorative meanings of abuse, both related to inefficiency and misuse of money
(Lawton \& Rose, 1984). Bureaucracy is also a specific method of determining how the organization is structured and the method by which the work of the organization is accomplished (Lawton \& Rose, 1984). In the context of the transfer of authority to manage secondary education, it has an impact on local government institutions, both related to organizational structure, hierarchies within the organization, adding or reducing tasks and functions, resource management to budget management.

The transfer of authority to manage secondary education also has an impact on public services. There are at least three characteristics to determine a service is categorized as a public service, namely the nature of the service is more for social benefits than economics, service users are seen in their position as citizens and the characteristics of complex service users from various dimensions such as individuals, families or communities (Dwiyanto, 2011). The public interest in state organizations in principle must be served by the government in accordance with the basic rules and established procedures (Kamarni, 2011). It is in this context that public services after the transfer of authority must be considered. Changes in the local bureaucracy with new institutional structures, work methods and so on have an impact on public services in the secondary education sector. Even if there is a transfer of authority, the general standards for good public service quality, namely reliability, responsiveness, confidence, empathy and tangibles must always be realized (Parasuraman et.al, 1998).

\section{METHOD}

This study uses a qualitative approach that aims to build a detailed view that is formed with words, a holistic and complex picture and does not use statistical analysis stages or other quantification methods (Moleong, 2014:6). The research location is the province of North Sumatra by taking samples of Medan City as an urban area and Batubara Regency representing a rural area. The primary data in this study were in-depth interviews with provincial and district/city government officials, school principals, educators, parents and community elements. Secondary data is obtained through the collection of scientific references, official documents, regulations and other documents relevant to the object of research. Data analysis ia carried out qualitatively following the cycle used which consisted of organizing data, reading and making memos for further process of describing, classifying and interpreting data into themes, interpreting data; presenting and visualizing data (Creswell, 2015:255). Data validation is carried out using triangulation techniques and data sources as well as conducting credibility standards and conformity standards (Lincoln in Bungin, 2012:59) 


\section{RESULT AND DISCUSSION}

\subsection{Secondary Education Management in a Decentralized Framework}

Discussing on the implementation of education in Indonesia cannot be separated from the discussion about the state administration system within the framework of a unitary state. This assertion is important because the units of government under the national government are not sovereign by nature. This is different from the constitutional system practiced in federal states where states have autonomous sovereignty such as carrying out certain policies such as foreign relations, justice, politics and other aspects with or without the approval of the federal government

Within the framework of a unitary state as practiced by Indonesia, there are various absolute or absolute powers that are only owned by the central government and government units under it, such as provincial and district/city autonomous regions that do not have it. In accordance with the Law on Regional Government through Law Number 22/1999, Law Number 32/2004 and Law Number 23/2014, the absolute authority is foreign policy, defense, security, judiciary, national monetary and fiscal as well as religion. This absolute authority applies to all autonomous regions in Indonesia except for special autonomous regions such as Aceh Province which has the authority to administer government and public services in the religious sector.

The implementation of absolute authority possessed by the central government in practice has consequences for the existence of dualism in the administration of government and public services in certain sectors, including in this discussion the implementation of education. In general, the implementation of basic education to secondary education is the domain of the provincial government and city district governments. However, in accordance with the absolute authority possessed by the central government, the form of formal religious education in autonomous districts/municipalities is under the authority of the central government. This reality at least shows that the central government has a wider authority than what is outlined in Law No. 23/2014. When viewed from the data in the province, the presence of the central government with its authority in the secondary education sector is quite significant where more than $20 \%$ (534 of 2,583) units of secondary education institutions are central government institutions that serve $13 \%$ of the total students at the secondary education level.
Table 2. Comparison of Number of School and Students under the Management of the North Sumatra Provinces and the Central Government

\begin{tabular}{|c|c|c|c|c|c|c|}
\hline \multirow{2}{*}{$\begin{array}{l}\mathrm{N} \\
\mathrm{O}\end{array}$} & \multicolumn{3}{|c|}{ Provincial Government } & \multicolumn{3}{|c|}{ Central Government } \\
\hline & $\begin{array}{l}\text { Type } \\
\text { of } \\
\text { Educat } \\
\text { ion }\end{array}$ & $\begin{array}{c}\text { Num } \\
\text { ber } \\
\text { of } \\
\text { Scho } \\
\text { ols }\end{array}$ & $\begin{array}{c}\text { Num } \\
\text { ber } \\
\text { of } \\
\text { Stude } \\
\text { nts }\end{array}$ & $\begin{array}{l}\text { Type } \\
\text { of } \\
\text { Educa } \\
\text { tion }\end{array}$ & $\begin{array}{c}\text { Num } \\
\text { ber } \\
\text { of } \\
\text { Scho } \\
\text { ols }\end{array}$ & $\begin{array}{c}\text { Num } \\
\text { ber } \\
\text { of } \\
\text { Stude } \\
\text { nts }\end{array}$ \\
\hline 1. & $\begin{array}{l}\text { Public } \\
\text { High } \\
\text { School } \\
\text { (SMA) }\end{array}$ & 427 & $\begin{array}{c}245.4 \\
77\end{array}$ & $\begin{array}{l}\text { Public } \\
\text { Islami } \\
\text { c High } \\
\text { Schoo } \\
1 \\
\text { (MAN } \\
\text { ) }\end{array}$ & 42 & $\begin{array}{c}3181 \\
7\end{array}$ \\
\hline 2. & $\begin{array}{l}\text { Private } \\
\text { High } \\
\text { School } \\
\text { (SMA) }\end{array}$ & 647 & $\begin{array}{c}140.1 \\
42\end{array}$ & $\begin{array}{c}\text { Privat } \\
\text { e } \\
\text { Islami } \\
\text { c High } \\
\text { Schoo } \\
1 \\
\text { (MAS } \\
\text { ) }\end{array}$ & 492 & $\begin{array}{c}7335 \\
1\end{array}$ \\
\hline 3. & $\begin{array}{c}\text { State } \\
\text { Vocati } \\
\text { onal } \\
\text { High } \\
\text { School }\end{array}$ & 268 & $\begin{array}{c}138.9 \\
85\end{array}$ & & & \\
\hline 4. & $\begin{array}{l}\text { Private } \\
\text { Vocati } \\
\text { onal } \\
\text { School }\end{array}$ & 707 & $\begin{array}{c}184.1 \\
28\end{array}$ & & & \\
\hline & Total & $\begin{array}{c}2.04 \\
9\end{array}$ & $\begin{array}{c}708.7 \\
32\end{array}$ & & 534 & $\begin{array}{c}105.1 \\
68\end{array}$ \\
\hline
\end{tabular}

Source: Central Bureau of Statistics of North Sumatra Province (2021)

Regulation of Law Number 22 of 1999 concerning Regional Government, as the main legal umbrella in the implementation of decentralization, places the secondary education sector into the domain of authority of the district/municipal government. The implementation of secondary education based on this mechanism runs for at least fifteen years, pricesely namely 2001 to 2014. Based on the latest regulation, the implementation of secondary education is described as a concurrent area of authority in the sense that all levels of government, both central and provincial and district/municipal autonomous regions have their respective authorities. However, the pendulum point of the provision of secondary education into the territory of the provincial government which was previously the territory of the district government.

\subsection{Challenges of Local Bureaucracy}

One of the logical consequences of the transfer of the authority to manage secondary education from the 
district/municipal governments to the provincial government's authority is the structuring of the local government's institutional structure. If so far the management of education has been with the district/municipal education office, after the transfer of authority, it will be with the Provincial Education Office. This transfer of authority then has an impact on the adjustment of the bureaucratic structure both regarding institutions, authority structures and hierarchies, span of control and sustainability of secondary education programs.

At the level of the provincial education office, 2 units of echelon III positions were formed, each in charge of Senior High School (SMA) and Vocational
High School (SMK) Development. Moreover, the Education Office of North Sumatra Province formed a branch office which was an echelon III unit. The establishment of a branch office is mainly based on the number of school units in an area. In case there are many schools in a district/municipal, the branch office may be formed in more than 1 unit. On the other hand, if in a district/municipal the number of senior high schools is very limited, then a branch office may be established in the capital of a certain district/municipal with a scope of work area that exceeds 1 district/municipal. At the branch office level, 2 echelon IV units were formed, each consisting of the SMA and PKLK sections and the SMK sections.

Table 3. Establishment and Division of Work Areas for Education Branch Offices

\begin{tabular}{|l|l|l|}
\hline No & \multicolumn{1}{|c|}{ Name of Provincial Education Branch Office } & \multicolumn{1}{c|}{$\begin{array}{r}\text { Work Area } \\
\text { District/Municipality) }\end{array}$} \\
\hline 1. & Sibolga & Sibolga dan Tapanuli Tengah \\
\hline 2. & Tanjung Balai & Tanjung Balai dan Labuhanbatu Utara \\
\hline 3. & Sei Rampah & Tebing Tinggi dan Serdang Bedagai \\
\hline 4. & Medan Utara & Medan \\
\hline 5. & Medan Selatan & Padang Lawas dan Padang Lawas Utara \\
\hline 6. & Gunungtua & Gunung Sitoli, Nias dan Nias Utara \\
\hline 7. & Gunung Sitoli & Deli Serdang \\
\hline 8. & Sunggal & \\
\hline 9. & Lubuk Pakam & Toba dan Samosir \\
\hline 10. & Balige & Labuhanbatu dan Labuhanbatu Selatan \\
\hline 11. & Rantau Parapat & Tapanuli Utara dan Humbang Hasundutan \\
\hline 12. & Humbang Hasundutan & Pematang Siantar dan Simalungun \\
\hline 13. & Pematang Siantar & Karo, Dairi dan Pakpak Bharat \\
\hline 14. & Kabanjahe & Batubara dan Asahan \\
\hline 15. & Kisaran & Nias Selatan dan Nias Barat \\
\hline 16. & Teluk Dalam & Langkat dan Binjai \\
\hline 17. & Stabat & $\begin{array}{l}\text { Tapanuli Selatan, } \\
\text { Mandailing Natal }\end{array}$ \\
\hline 18. & Padang Sidimpuan & Mansidempuan \\
\hline
\end{tabular}

Source: North Sumatra Provincial Education Office, 2021.

The branch unit of the education office places three officials at the level of echelon IV, namely the Head of the Administrative Subdivision, to the High School and Special Education and Special Service (PKLK) Sections and the Head of the Vocational School. When viewed from this institutional structure, the organizational formation that was formed was still more focused on technical matters of education management by only placing two sections that were directly in charge of secondary education. To create the ideal goal of transferring authority, such as improving the quality of education, it is deemed necessary to establish one special section which deals with program planning and competency development of educators. Educational management affairs should ideally not deal with the administration of personnel, facilities and infrastructure, but rather a field or section that takes care of the ultimate goal of education, such as the program planning section and improving the competence of educators or education staff.

Along with the formation of work units in charge of SMA and SMK development both at the provincial and branch office in each region, the problem that needs to be assessed is the span of control. The principle of span of control relates to the number of subordinates that can be effectively controlled by a leader in an organization (Agustina, 2013). When viewed from the institutional structure of the branch office that was formed, the span of supervision control is not effective, especially since the number of schools, educators and students in a branch office work area is also large. 
Table 4. Formation and Division of Work Areas of the

\begin{tabular}{|c|c|c|c|c|}
\hline No. & Name of Provincial Education Branch Office & $\begin{array}{l}\text { Number of SMA } \\
\text { and SMK Units }\end{array}$ & $\begin{array}{l}\text { Number of } \\
\text { Teachers }\end{array}$ & $\begin{array}{l}\text { Number of } \\
\text { Students }\end{array}$ \\
\hline 1. & Sibolga & 61 & 1.570 & 25.709 \\
\hline 2. & Tanjung Balai & 60 & 1.510 & 17.803 \\
\hline 3. & Sei Rampah & 111 & 1.326 & 38.292 \\
\hline 4. & Medan Utara & \multirow[t]{2}{*}{384} & \multirow[t]{2}{*}{8.084} & \multirow[t]{2}{*}{128.928} \\
\hline 5. & Medan Selatan & & & \\
\hline 6. & Gunungtua & 48 & 1.171 & 14.007 \\
\hline 7. & Gunung Sitoli & 161 & 3.458 & 59.257 \\
\hline 8. & Sunggal & \multirow[t]{2}{*}{185} & \multirow[t]{2}{*}{4.761} & \multirow[t]{2}{*}{81.272} \\
\hline 9. & Lubuk Pakam & & & \\
\hline 10. & Balige & 56 & 1.439 & 23.183 \\
\hline 11. & Rantau Parapat & 106 & 2.041 & 34.202 \\
\hline 12. & Humbang Hasundutan & 77 & 2.239 & 35.194 \\
\hline 13. & Pematang Siantar & 152 & 3.853 & 61.346 \\
\hline 14. & Kabanjahe & 86 & 2.497 & 40.056 \\
\hline 15. & Kisaran & 128 & 2.580 & 44.955 \\
\hline 16. & Teluk Dalam & 141 & 2.808 & 26.501 \\
\hline 17. & Stabat & 190 & 3.836 & 62.009 \\
\hline 18. & Padang Sidimpuan & 107 & 3.227 & 40.468 \\
\hline & Jumlah & 2.053 & 46.400 & 733.182 \\
\hline
\end{tabular}

Source: North Sumatra Provincial Education Office, 2021; Central Bureau of Statistics of North Sumatra Province (2021)

During the Covid-19 pandemic circumstance with the intense use of information technology, this span of control is not too problematic because online meeting application media can be used to monitor and supervise schools. However, when under normal conditions before the Covid-19 pandemic this range of control was not effective. With the number of employees who only number around 20 employees at the branch office, they will not be able to carry out effective monitoring and supervision (Interview, 2021). However, the concept of monitoring and supervision carried out by the educational branch office itself is not comprehensive in nature but only takes a few school samples or class samples (Interview, 2021).

It must be admitted that one of the public criticisms and local government criticisms related to this transfer of authority is the problem of program sustainability for the advancement of the education sector. In the case of North Sumatra Province, there are several regions that have made good "investments" in the secondary education sector as did the City of Medan. With a good fiscal capacity, it provided incentives in the form of food allowances for civil servants who work as educators and education staff at secondary education institutions in. When the transfer of authority occurs, the allowances immediately disappear because so far the provincial government has not provided such allowances (Interview, 2021). However, there is a significant change in the welfare benefits for structural employees who work in the education branch office, where these structural officials previously worked for the district/municipal government. The case experienced in Medan is in fact different from the case of the Batubara. When the management of secondary education became the authority of the district, the level of welfare and its mechanism was actually lower than the condition after the transfer of authority. In the period prior to the transfer, salaries for honorary teachers or non-permanent teachers were not covered by the district budget. The salaries of non-permanent educators are taken from school fees (SPP) obtained by the school. After the transfer of authority, the remuneration for nonpermanent education personnel comes from the provincial budget so that school fees can be used for other sectors (Interview, 2021).

Regarding the investment in the secondary education sector that has been well done by the previous city/municipal, it should be continued through the existing mechanism. For district/municipal that provide welfare benefits for educators and previous education staff or provide scholarships for students because of their good fiscal capacity, it can still be done even though the management of secondary education has shifted. Informants from structural officials at the education office of North Sumatra Province said that inter-regional sectorial egos should not be developed within the framework of management and development of secondary education. 


\begin{abstract}
"Sectorial ego should not occur in the transition of education management. We know that human resources belong to the regions. Provinces do not have citizens directly. So if they want to provide incentives or scholarships, they should still be able to, for example, provide their budget to the provincial government through a grant scheme. There is still a mechanism if we really want to" (Interview, 2021)
\end{abstract}

\subsection{Prospect of Transfer of Authority: Public Administration Perspective}

One of the important points in the transfer of the authority to manage secondary education is the effort to increase the neutrality of the bureaucracy. In the ideal context, education and education personnel must prioritize their duties as public servants who must provide services fairly and equitably to the community. However, there are many assumptions that the bureaucracy is one of the important political structures in the democratization process where bureaucrats become agents of political socialization who play a very important role in the success of the implementation of election contestation (Dwimawanti, 2009). In this context, the neutrality of the bureaucracy is hurt by local political interventions such as the confession of research informants in Batubara Regency.

This also confirms the opinion of Lawton \& Rose (1984) which defines bureaucracy as a form of government where people are considered to work for the government. In the context of local politics, there are at least three general reasons why it is easy for teachers or educators to be directly involved in the post-conflict local election. Firstly, teachers play a strategic role, namely education that is in direct contact with the public. Secondly, in the realm of regional autonomy, teachers are easier to influence through the bureaucratic system by using the hands of the Head of the Education Office. Third, the teacher community is still seen as a public figure that is so easy to approach the community to influence them to choose certain candidate pairs in the Pilkada (Herawati, 2017).

"Indeed, when I became part of the district government, the smell of politics was very, very close. This is partly because we live together in one community with a local political network and have a high intensity of meetings with that network. Even after becoming part of the provincial (government) there is nothing like it used to be. We don't know much about the network of contestants in the governor's election" (Interview, 2021).
The next point related to the transfer of authority for the management of secondary education is the efficiency of the bureaucracy. The number of human resources for structural positions is automatically reduced which is accompanied by savings in state finances for financing salaries or allowances for structural and functional officials. The district/municipal education office prior to the transfer of authority amounted to 132 structural officials. Assuming that on average each echelon IV has 4 implementing staff, the total implementing staff is 528 people. With this transfer, there are only 72 structural officers of the provincial office in the district/municipal with a total of 288 implementing staff. Based on this calculation, the efficiency of the budget through this takeover has almost reached $50 \%$. However, this bureaucratic efficiency does not necessarily guarantee effectiveness in the management of secondary education as previously described.

This transfer of authority for the management of secondary education directly or indirectly contributes to the creation of professional educators and education personnel. The improvement of professionalism is directly carried out through a series of capacity building activities made by the provincial government which previously was minimally carried out by the district/municipal government. The direct forms of capacity building include the implementation of technical guidance, training, discussion forums, and working visits and so on.

Increasing the professionalism of educators and education staff indirectly occurs when they can exchange information, experience and knowledge with other parties, both peer groups and external parties in these capacity building activities. Sharing information, knowledge and experience can be related to the management of teaching and learning activities, improving educational facilities and improving educational facilities so as to enable them to duplicate programs or create programs that are better than other school experiences (Interview, 2012)

\begin{abstract}
"We can learn a lot from other regions, both in the forums held and during visits to schools in other regions. There are things that we think are good to be practiced in other schools, we imitate and apply in this school. This is a simple example, CCTV, in Medan there are many schools that use this tool and we think it is good to make it in this school. Theft can be monitored, what are the activities of students in the oldest school environment" (Interview, 2021)
\end{abstract}

The existence of local government political intervention in the management and management of educators basically injures the professionalism of teachers as educators. The smell of nepotism in the recruitment of teachers, such as honorariums or in 
receiving assistance for providing education, is common when secondary education is under the jurisdiction of the district/municipal. This is because the policy makers regarding the formation of education personnel such as honorary teachers live in the same geographical environment as prospective educators and honorary teachers. Regarding assistance in the provision of education, so far, nepotism has often intervened (Interview, 2021). With the transfer of authority, local intervention in teacher recruitment is less likely. This is based on the fact that policy makers with prospective education personnel and honorary teachers live in different areas or communities so that nepotistic practices are easier to eliminate (Interview, 2021). With this transfer of authority to manage secondary education, the practice of nepotism can be minimized along with stricter technical guidelines related to the appointment of educators and education staff.

The general criticism of public services held by local government institutions so far is regarding the transparency of public services. The lack of transparency in the management of education and public services in the education sector is caused by many factors, ranging from the low integrity of public officials, the practice of nepotism or even the practice of corruption in the use of the education budget. Along with this transfer of authority, the positive side of the public service aspect is the emergence of the embryo of transparency. Research informants said that administration and public education services are currently done online or using the concept of egovernment where previously the process was done more conventionally. Research informants also said that, for budget planning, a lot of it has been done online and centrally. This does not allow for double budgeting or a lot of assistance for certain schools as has been widely practiced when secondary education was the domain of the district/municipal government.

"The positive thing from this transfer of
authority which is very clear is the
transparency of education management,
especially for the provision of assistance to
schools. Now it's more transparent, in the past
the element of nepotism was still there, so only
those schools could. Now it is clear in the
system, there can no longer be a double-
budgetting; the system will immediately detect
it" (Interview, 2021)

\section{CONCLUSION}

This study potrays the bureaucratic challenges related to the transfer of authority to manage secondary education are in three areas which are institutional structure, span of control and program sustainability. The institutional structure is still more focused on the technical affairs of education management by only placing two sections that deal directly with secondary education. The span of control of the organization is faced with the problem of how effective mechanisms are to monitor, supervise and develop schools that exceed the average between regions. The sustainability of the program is faced with the condition of the emergence of district/municipal egocentricity and the minimal contribution of them to developing secondary education which is no longer the domain of their authority.

The prospects of this transfer are in the area of bureaucratic neutrality, bureaucratic efficiency, professionalism, nepotism practices and transparency of public services. Bureaucratic neutrality can be achieved when the opportunities for local political intervention in the world of education are getting smaller. The professionalism is more guaranteed with a series of capacity building carried out by the provincial government. Bureaucratic efficiency is achieved when structural positions in educational institutions are getting leaner accompanied by fewer executive positions. The practice of nepotism in the education bureaucracy has less chance because some officials and educational staff are no longer from the same region or community. Lastly, the transparency of education services and management is more guaranteed where the dominant public service is done online and centrally.

\section{RECOMMENDATION}

This study scientifically recommends the need to conduct further research with a wider scope and more comprehensive aspects of public administration. The study also practically recommends the need for good institutional arrangements regarding the structure of the branch office which more accommodates efforts to achieve improving the quality of education. In addition, it is necessary to involve collaborative participation of district/municipal government as the resource owner to improve the quality of education and public services in the secondary education sector such as the provision of education grants by districts/cities to be further managed by the province

\section{ACKNOWLEDGMENT}

The authors would like to thank the chancellor of the Universitas Sumatera Utara through the Chairman of the Lembaga Penelitian USU for funding this study through the scheme of NON PNBP in 2021 contract number: 6789/UN5.1.R/PPM/2021. Awards are also conveyed to all parties participating in this research.

\section{REFERENCES}

[1] Agustina, M.R., Evaluasi Terhadap Struktur Organisasi Dan Tata Kerja Perangkat Daerah Pada Pemerintah Kabupaten Kotabaru, Jurnal Ilmu Politik dan Pemerintahan Lokal, 2 (1): 107-125, 2013. 
[2] Armansyah, Y. , Menyoal Relevansi Kebijakan Otonomi Daerah dan Otonomi Pendidikan Dikaji dari Kesejahteraan Masyarakat, Journal of Islamic Education Management, El-Idare, Vol. 2 (1): 141160, 2016.

[3] Bungin, B. (ed), Analisis Data Penelitian Kualitatif: Pemahaman Filosofis dan Metodologis ke Arah Penguasaan Model Aplikasi. Jakarta: PT. Raja Grafindo Persada, 2012.

[4] Burki, S. J., Perry, G., \& Dillinger, W. R. (1999). Beyond the Center: Decentralizing the State. Washington DC: World Bank, 75.

[5] Common, R., Flynn, N., Mellon, E., Managing Public Service: Competition and Decentralization, Butterwoth Heinemann:Oxford,Boston, Johannesburg, Meulbourne New Delhi, Singapore, 1998.

[6] Creswel, J.W., Penelitian Kualitatif \& Desain Riset: Memilih Diantara Lima Pendekatan. Yogyakarta: Pustaka Pelajar Bintoro, 2015.

[7] Denhardt, R.B, Theories of Public Organisation, Fifth Edition, Thomson Wadsworth:USA, 2008

[8] Disdik Kalteng , Pengalihan Kewenangan SMA Jangan Buat Renggang Hubungan Pemprov dan Pemkab" dalam https://disdik.kalteng.go.id/pengalihan-

kewenangan-sma-jangan-buat-rengganghubungan-pemprov-dan-pemkab/ diakses tanggal 03 Maret 2021 Pukul 14.25 WIB.

[18] Oates, W. E., Fiscal Federalism. New York: Harcourt Brace Jovanovich, 1972.

[19] Parasuraman, A., Zeithaml, V.A.and Berry, L.L. Servqual: A Multiple Item Scale for Measuring Consumer Perceptions of Service Quality, Journal of Retaling, 64(1):12-40, 1998.

[20] Rondinelli, D. A., Nellis, J. R., \& Cheema, G. S., Decentralization in Developing Countries. A Review of Recent Experience, Word Bank Vol. 581: 5-12, 1984.

[21] Sujarwoto, Why Decentralization Works And Does Not Works? A Systematic Literature Review, JPAS Vol. 1 (3): 1-10, 2017.

[22] Tiebout, C. M., A Pure Theory of Local Expenditures. Journal of Political Economy, 64(5), 416-424, 1956.
[9] Dwimawanti, I.H. Netralitas Birokrasi Dan Kualitas Pelayanan Publik, Jurnal kebijakan dan Manajemen PNS, 3(1): 47-54, 2009.

[10] Dwiyanto, A., Reformasi Birokrasi Publik di Indonesia. Yogyakarta: Gadjah Mada University Press, 2006.

[11] Lawton, A. \& Rose, A., Organisation and Managent in The Public Sector", Second Edition, Pitman Publishing: London, 1984.

[12] Habibi, F., Transisi Peralihan Kewenangan Bidang Pendidikan Sma/Smk Di Provinsi Banten, Jurnal Sawala, Vol 5 (2): 11-22, 2017.

[13] Herawati, N.R., Analisis Politik Alih Kewenangan Pengelolaan Guru Sma/Smk Dari Pemerintah Kabupaten/Kota Kepada Pemerintah Provinsi, Jurnal Ilmu Sosial, 16 (2): 72-93, 2017.

[14] Kamarni, N., Analisis Pelayanan Publik Terhadap Masyarakat (Kasus Pelayanan Kesehatan di Kabupaten Agam), Jurnal Manajemen dan Kerirausahaan, 2 (3): 85, 2011.

[15] Keputusan Mahkamah Konstutusi Republik Indonesia Nomor: 30/PUU-XIV/2016

[16] Mawhood, P. Local Government in the Third World: The Experience of Decentralization in Tropical Africa. New York, Brisbane, Toronto, Singapore: John Wiley \& Sons Ltd, 1983.

[17] Mills, A., Vaugen, J.P., Smith, Duane L.,\& Tabibzadeh, Iraj., Health System Decentralization: Concepts, Issues and Country Experience. Geneva: World Health Organization, 1990. 